\title{
Accidental intoxication of the infant-juvenile population in households: profiles of emergency care
}

\author{
Intoxicação acidental na população infantojuvenil em ambiente \\ domiciliar: perfil dos atendimentos de emergência \\ Intoxicación accidental en la población infantojuvenil en ambiente \\ domiciliario: perfil de las atenciones de emergencia
}

Jackeline Gonçalves Brito ${ }^{1}$, Christine Baccarat de Godoy Martins ${ }^{2}$

${ }^{1}$ Master's Degree, Post-Graduate Program, Universidade Federal de Mato Grosso, Cuiabá, MT, Brazil.

${ }^{2}$ Adjunct Professor, Faculty of Nursing, Universidade Federal de Mato Grosso, Cuiabá, MT, Brazil.

\begin{abstract}
Objective: Analyzing profiles of intoxication and accidental poisoning of infant-juvenile population (0-24 years) in the household, treated at a reference facility for Emergency and Primary Care, during the year 2013. Method: A descriptive, cross-sectional study. Data were analyzed using Epi-Info, by way of simple and bivariate analyzes. The project was approved by the Research Ethics Committee (protocol 405.578). Results: There were 45 intoxications, with a prevalence of males (60.0\%), aged 1-4 years $(71.1 \%)$. Among children under one, there was a higher frequency of pesticide poisoning $(66.6 \%)$, between the ages of 1-4 by cleaning products (34.4\%), and between 5-9 years of age by pharmacological substances $(66.6 \%)$. The primary assistance was provided only at health institutions, with hospital admissions in $24.4 \%$ of the cases. Conclusion: The importance of prevention through legislation is evident, in order to ensure greater safety in packaging of various products, and community awareness to eliminate risks in the household environment.
\end{abstract}

\section{DESCRIPTORS}

Child; Poisoning; Accidents, Home; Toxicology; Pediatric Nursing. 


\section{INTRODUCTION}

Intoxication or poisoning is caused by ingestion, inhalation or exposure to some toxic substance (harmful) to the body which can cause permanent damage or even death in cases where individuals are not assisted in time ${ }^{(1)}$. The domestic environment has a wide variety of agents such as toxic plants, drugs, pesticides, cleaning and hygiene products that represent risk for intoxication and poisoning when not stored or used correctly ${ }^{(2)}$.

Therefore accidental poisoning in the household environment is among the most common domiciliary accidents in the infant-juvenile population, and occupies a prominent position in emergency services and emergency room visits $^{(2-5)}$.

According to the Ministry of Health in Brazil, from August 2013 to August 2014, there were 1437 admissions due to poisoning or accidental intoxication due to poisonous substances in the age group of 0-24 years. These hospitalizations caused an expense of nearly 500 thousand reias for the Unified Health System ${ }^{(6)}$.

Brazil counts on the National Information System on Poisoning (SINITOX), an information network with 36 control centers in different regions of Brazil. In Mato Grosso it is represented by the Cuiabá Anti-Poison Information Centre, located in the Cuiabá Municipal Emergency Room Hospital (HPSMC). 2011 data show a higher frequency of poisoning in Midwest region by drugs (23.18\%) and household cleaning products $(10.34 \%)$. There was a predominance of males in $54.63 \%$ of the cases ${ }^{(7)}$.

The American Association of poison control center 2012 annual report (NPDS) reported 2,275,141 human exposures to toxic substances, with the most frequent being medicines, cosmetics / personal care products and household cleaning substances ${ }^{(8)}$.

Recent studies in India, Africa, Malaysia and Palestine have also highlighted the large proportion of accidental poisoning in the home environment, being caused by various household cleaning products, medicines, plants, pesticides and petroleum derivates ${ }^{(9-12)}$.

Therefore, the severity of domiciliary intoxication and poisoning accidents in infant-juvenile population is significant. Given the lack of research on these events in the Mato Grosso region, it is necessary to know the circumstances and factors associated with these accidents so preventive and educational measures can be tracked.

Thus, the present study aimed to analyze the intoxication and accidental poisoning profile in the household environment for the infant-juvenile population (0-24 years old) treated at a referral facility for emergency care, during the year 2013.

\section{METHOD}

This is a descriptive cross-sectional cohort study, with retrospective data collection and quantitative analysis. The study population consisted of children, adolescents and young adults, victims of accidental exogenous poisoning which occurred in the household environment and treated by a reference public service in emergency rooms for Cuiaba and Region.

The study included the visits due to accidental poisoning - codes X40 to X49 of the International Classification of Diseases (ICD-10) - poisoning (intoxication) and accidental exposure to harmful substances, as follows: X43: Exposure to drugs acting on the autonomic nervous system; X44: Exposure to other drugs, medicaments and biological substances not specified; X46: Exposure to organic solvents and halogenated hydrocarbons and their vapors; X48: Exposure to pesticides and X49: Exposure to other harmful and unspecified chemicals.

Cases of intentional intoxication and or undetermined intention were excluded.

For data collection we used a previously-tested form with 25 closed questions and one open question for the account of exogenous intoxication. The variables studied were: victim profile (sex, age group, city of residence), the profile of exogenous poisoning (type of intoxication, product which caused the intoxication, time of day / day of week / month on which the intoxication occurred), service profile (site of the first service, who brought them to the health service and time between intoxication and care in the health service), and clinical evolution of the victim (immediate physical damage, discharge, referral, hospitalization, drop out, immediate death).

Data were collected from the records or responsiveness, then filed in the proper sector's own filing records. We checked all emergency room visits which occurred during the year 2013 (January 1 to December 31, 2013). Regarding the inclusion and exclusion criteria, the patients' records relating to domiciliary poisonings in patients of $0-24$ years needed to have had their information input onto the data collection form.

Data collection took place between January to March 2014, and the data were processed by the Epi-Info - version 3.4.3. For the analysis, descriptive and inferential statistics were used from simple and bivariate analyses (chi-square statistical test, considering statistically significant results when the $p$ value was equal to or less than 0.05 ).

This research was approved on the date of 25.09.2013 by the Ethics Committee of the Julius Müller University Research Hospital (HUJM) under the protocol 405578. Accordingly, we have respected all ethical principles contained in the National Healthcare Council Resolution 466/2012.

\section{RESULTS}

We studied 45 cases of accidental exogenic poisoning involving children, youth and adolescents in the household environment in 2013. More than half of the victims were male (27 for $60.0 \%$ ) and $40 \%$ were female ${ }^{(18)}$. The most affected age group was 1-4 years old (32 for 71.1\%) followed by $5-9$ years ( 6 for $13.3 \%$ ), 10-14 years (4 for $8.9 \%$ ) and less than a year (3 for 6.7\%). There were no casualties over 14 years old. The majority being $95.6 \%$ (43) lived in Cuiabá and only $4.4 \%$ (2) came from another municipality.

Regarding the classification of poisoning according to the International Classification of Diseases (ICD-10) and 
the victim's age ( $\mathrm{p}=0.3233)$ among children under one year, more than half were pesticide poisoning victims (66.7\%). Among children 1-4 years, most often the poisoning was due to other harmful and unspecified chemicals (37.5\%), followed by exposure to pesticides (25.0\%). For the ages of 5-9 years, more exposure to other drugs, medicaments and unspecified biological substances occurred (50.0\%). And in the age group 10-14 years, accidents were distributed evenly among the different types (Table 1).
Table 1 also lists the classification of poisoning (ICD10) with the gender of the victim $(p=0.5194)$, showing that the highest frequency of poisoning among girls was due to exposure to other drugs, medicaments and unspecified biological substances (38.9\%); among boys it was by exposure to other harmful and unspecified chemicals (37.0\%). However, there was no statistical significance to suggest association between type of poisoning and age or gender of the victim.

Table 1 - Distribution of exogenous domiciliary poisoning in the population of 0 to 24 years treated at the Emergency Unit of Cuiabá Municipal Hospital, according to the classification of intoxication (ICD-10), age group and gender of victims - Cuiabá, Brazil, in 2013.

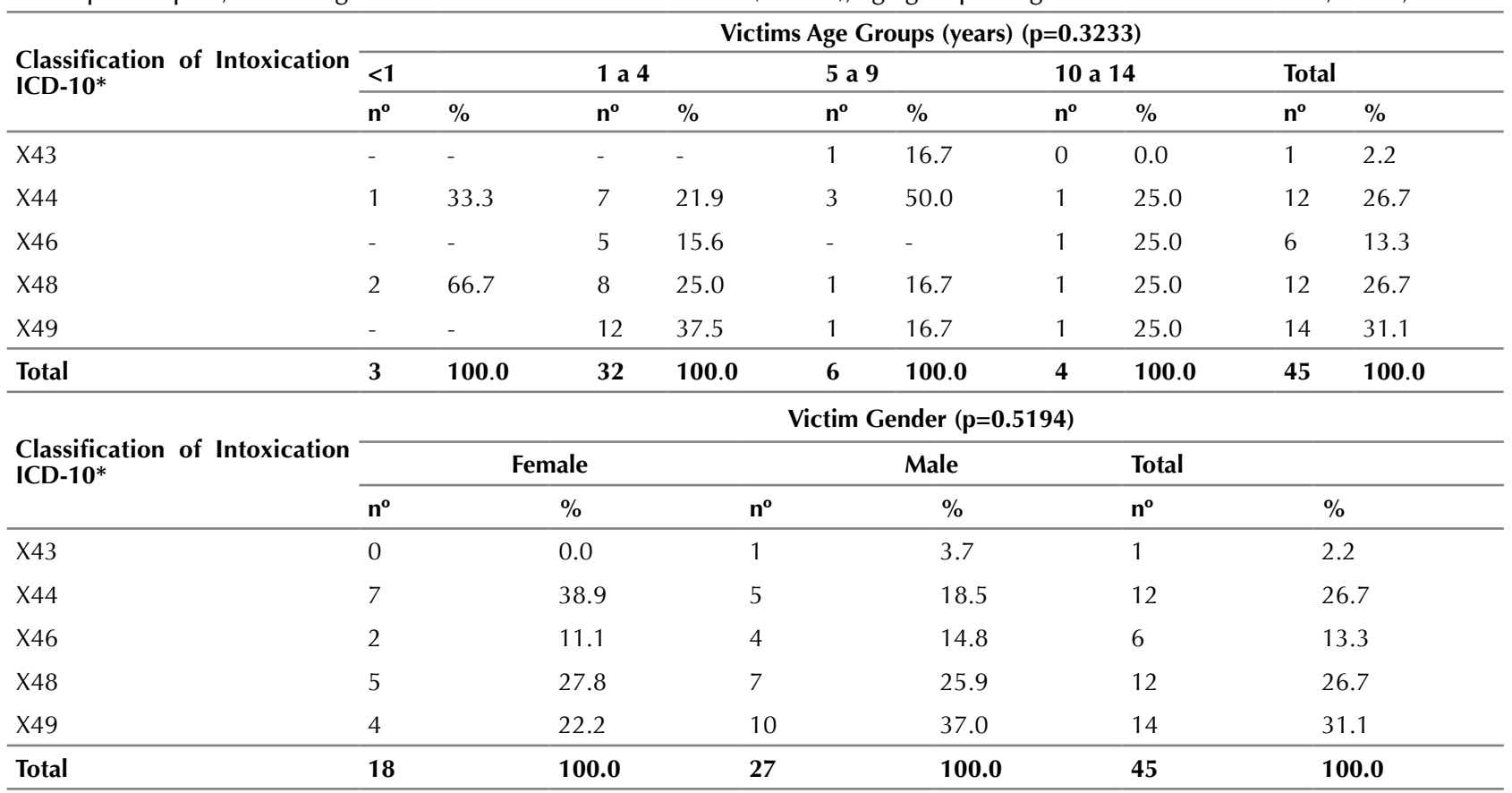

${ }^{*} \mathrm{X} 43$ : Exposure to other drugs acting on the autonomic nervous system.

$\mathrm{X} 44$ : Exposure to other drugs, medicaments and unspecified biological substances.

$\mathrm{X} 46$ : Exposure to organic solvents and halogenated hydrocarbons and their vapors.

$\mathrm{X} 48$ : Exposure to pesticides.

X49: Exposure to other harmful and unspecified chemicals.

The crossing of the product involved in the intoxication and the age of the victim is shown in Table 2. However, it was not possible to apply the Chi-square test ( $p$-value) because this information was taken from the open question that included the accident report, being complementary to the ICD-10 classification. According to Table 2, it was observed that children under one year had a higher frequency of poisoning caused by pesticides $(66.7 \%)$, such as rat poison, insecticide, and aerosol insecticide; 1 -4 years from cleaning products $(34.4 \%)$ such as detergent, bleach, stain remover; and 5-9 by pharmacological products (66.6\%) such as a contraceptives, anticonvulsant, hypertension, eye drops and nasal decongestant. Other products $(25.0 \%)$ also caused intoxication in the group of 10-14 years, such as gasoline, super bonding glue, thinner, cresols, and plants (25.0\%) such as the desert rose, the dumbcane (Dieffenbachia seguine), pesticides (25.0\%) and pharmacological substances which were previously described (25.0\%).

Table 2 - Distribution of domiciliary exogenous poisoning in the population between 0 and 24 years treated at the Emergency Unit of Cuiabá Municipal Hospital, according to the product involved and the age of the victim - Cuiabá, Brazil, 2013.

\begin{tabular}{|c|c|c|c|}
\hline Classification ICD-10 & Product Involved & $\mathbf{n}^{\circ}$ & $\%$ \\
\hline Cleaning products & Detergent, bleach, stain remover & 11 & 24.4 \\
\hline Pharmaceutical substances & Contraceptives, anticonvulsant, hypertensive, eye drops, nasal decongestant & 11 & 24.4 \\
\hline Pesticides & Rat poison, insecticide, aerosol insecticides & 12 & 26.7 \\
\hline Other & Gasoline, "super bonding glue," thinner, cresols & 5 & 11.1 \\
\hline Plants & Desert Rose, dumbcane & 5 & 11.1 \\
\hline Not informed & not applicable & 1 & 2.3 \\
\hline Total & & 45 & 100.0 \\
\hline
\end{tabular}




\begin{tabular}{|c|c|c|c|c|c|c|c|c|}
\hline \multirow{3}{*}{ Product Involved } & \multicolumn{8}{|c|}{ Victim Age Groups } \\
\hline & \multicolumn{2}{|c|}{$<1$ year } & \multicolumn{2}{|c|}{1 - 4 years } & \multicolumn{2}{|c|}{$5-9$ years } & \multicolumn{2}{|c|}{10 - 14 years } \\
\hline & $\mathbf{n}$ & $\%$ & $\mathbf{n}$ & $\%$ & $\mathbf{n}$ & $\%$ & $\mathbf{n}$ & $\%$ \\
\hline Cleaning products & - & - & 11 & 34.4 & - & & - & - \\
\hline Pharmaceutical substances & 1 & 33.3 & 5 & 15.6 & 4 & 66.6 & 1 & 25.0 \\
\hline Pesticides & 2 & 66.7 & 8 & 25.0 & 1 & 16.7 & 1 & 25.0 \\
\hline Other & - & - & 4 & 12.5 & - & - & 1 & 25.0 \\
\hline Plants & - & - & 4 & 12.5 & - & - & 1 & 25.0 \\
\hline Not informed & - & - & - & - & 1 & 16.7 & - & - \\
\hline Total & 3 & 100.0 & 32 & 100.0 & 6 & 100.0 & 4 & 100.0 \\
\hline
\end{tabular}

The information for the period of occurrence of poisoning was not reported in more than half of the patients' records (60.0\%). Among the records that included the time of the accident, $24.5 \%$ occurred in the afternoon $(1 \mathrm{pm}-6 \mathrm{pm})$ and $13.3 \%$ occurred at night $(7 \mathrm{pm}-11 \mathrm{pm})$. The distribution of poisoning by day of the week showed a higher frequency on Friday (22.2\%), which along with Saturday and Sunday represented more than half of the incidents (55.5\%). The months of April (17.8\%) and June (13.3\%) had the most frequent incidence (Table 3 ).

Table 3 - Distribution of domiciliary exogenous poisoning in the population between 0 and 24 years treated at the Emergency Unit of Cuiabá Municipal Hospital, according to the profile of poisonings - Cuiabá, Brazil, 2013.

\begin{tabular}{lcc}
\hline Intoxication Profile & & \\
\hline Period of day when intoxications occurred & $\mathbf{n}^{\circ}$ & $\mathbf{\%}$ \\
Mornings (12am - 6am) & 1 & 2.2 \\
Afternoons (1pm - $6 \mathrm{pm})$ & 11 & 24.5 \\
Nights (7pm - 11pm) & 6 & 13.3 \\
Not Reported & 27 & 60.0 \\
Total & $\mathbf{4 5}$ & $\mathbf{1 0 0 . 0}$ \\
\hline Day of the week when intoxications occurred & $\mathbf{n}^{\circ}$ & $\mathbf{\%}$ \\
\hline Monday & 2 & 4.4 \\
Tuesday & 6 & 13.3 \\
Wednesday & 7 & 15.6 \\
Thursday & 5 & 11.1 \\
Friday & 10 & 22.2 \\
Saturday & 9 & 20.0 \\
Sunday & 6 & 13.3 \\
Total & $\mathbf{4 5}$ & $\mathbf{1 0 0 . 0}$ \\
\hline Month when intoxications occurred & $\mathbf{n}^{\circ}$ & $\mathbf{\%}$ \\
\hline January & 4 & 8.9 \\
February & 4 & 8.9 \\
March & 5 & 11.1 \\
April & 8 & 17.8 \\
May & 4 & 8.9 \\
June & 6 & 13.3 \\
Sugust & 1 & 2.2 \\
October & 5 & 11.1 \\
November & 3 & 6.7 \\
December & 1 & 2.2 \\
& 2 & 4.4 \\
Motal & 2 & 4.4 \\
& $\mathbf{4 5}$ & $\mathbf{1 0 0 . 0}$ \\
\hline
\end{tabular}

In almost all of the poisoning cases, primary assistance was provided in the health institution (95.6\%), and children were primarily brought to the health service by mothers $(73.3 \%)$. We were unable to determine the time between intoxication and assistance due to the time of the accident not being recorded in $64.4 \%$ of patients' records (Table 4).

Table 4 - Distribution of domiciliary exogenous poisoning in the population between 0 and 24 years treated at the Emergency Unit of Cuiabá Municipal Hospital, according to the assistance profile - Cuiabá, Brazil, 2013.

\begin{tabular}{lcc}
\hline Primary assistance site & $\mathbf{n}^{\circ}$ & \% \\
\hline Policlinic & 22 & 48.9 \\
Emergency Unit of Cuiabá Municipal Hospital & 18 & 40.0 \\
(HPSMC) & 2 & 4.4 \\
Family & 1 & 2.2 \\
In another Municipal Hospital & 1 & 2.2 \\
Urgency Clinic (UPA) & 1 & 2.2 \\
Others & $\mathbf{4 5}$ & $\mathbf{1 0 0 . 0}$ \\
Total & $\mathbf{n}^{\circ}$ & $\mathbf{\%}$ \\
\hline Who brought victim to the HPSMC & 33 & 73.3 \\
\hline Mother & 4 & 8.9 \\
Grandparent & 3 & 6.7 \\
Father & 3 & 6.7 \\
Not Reported & 1 & 2.2 \\
Mobile Emergency Assistance Service (SAMU) & 1 & 2.2 \\
Others & $\mathbf{4 5}$ & $\mathbf{1 0 0 . 0}$ \\
\hline Total & $\mathbf{\mathbf { n } ^ { \circ }}$ & $\mathbf{\%}$ \\
\hline Time elapsed between incident and assistance & 1 & 2.2 \\
\hline Less than 30 minutes & 6 & 13.3 \\
30 minutes to 1 hour & 3 & 6.7 \\
1 hour to 2 hours & 1 & 2.2 \\
More than 3 hours & 5 & 11.1 \\
Not Reported & $\mathbf{4 5}$ & $\mathbf{1 0 0 . 0}$ \\
\hline & & \\
Total & 19.4 \\
\hline
\end{tabular}

Cases of immediate physical harm after poisoning were not reported. As to clinical evolution of the victim, 73.3\% were discharged after treatment, but $24.4 \%$ were admitted, there was no immediate or during care death (Table 5). 
Table 5 - Distribution of domiciliary exogenous poisoning in the population between 0 and 24 years attended at the Emergency Unit of Cuiabá Municipal Hospital, according to the evolution of the victims - Cuiabá, Brazil, 2013.

\begin{tabular}{|c|c|c|c|c|c|c|}
\hline \multirow{2}{*}{$\begin{array}{l}\text { VICTIM CLINICAL } \\
\text { EVOLUTION }\end{array}$} & \multicolumn{2}{|c|}{ YES } & \multicolumn{2}{|c|}{ NO } & \multicolumn{2}{|c|}{ Total } \\
\hline & $\mathrm{n}^{\mathrm{o}}$ & $\%$ & $\mathrm{n}^{\mathrm{o}}$ & $\%$ & $\mathrm{n}^{\mathrm{o}}$ & $\%$ \\
\hline Discl & 33 & 73.3 & 12 & 26.7 & 45 & 100.00 \\
\hline $\begin{array}{l}\text { Referred to another } \\
\text { sector }\end{array}$ & - & - & 45 & 100.00 & 45 & 100.00 \\
\hline Inpatient & 11 & 24.4 & 34 & 75.6 & 45 & 100.00 \\
\hline Evasion/Dropout & 1 & 2.2 & 44 & 97.8 & 45 & 100.00 \\
\hline
\end{tabular}

\section{DISCUSSION}

45 primary consultations were carried out by virtue of household poisoning which occurred among children, adolescents and young people during the period of one year, which is equivalent to approximately four victims per month. In other national and international studies, a significant number also underlined care for accidental poisoning in the infant-juvenile population ${ }^{(8-9,13-16)}$, revealing the need for preventive measures to reduce the incidence, since all accidental events are considered predictable and preventable ${ }^{(17)}$.

Other studies corroborate our findings, in which there was a prevalence of male victims in accidental intoxications $^{(3,9-11,16,18-20)}$, which may be explained by behavioral factors, since boys are known to be more active and restless than girls, and social and cultural factors, as greater vigilance is given to girls, while boys are freer in their play and more exposed to the risks of the home environment for intoxication/poisoning ${ }^{(9-10)}$.

The higher frequency of poisoning in the age group of 1-4 years is similar to results of other samples ${ }^{(10-11,16,18,20)}$. These results are related to the development of characteristics inherent in this age group, in which children begin to interact with the environment, have curiosity for new and colorful things, and have the characteristic of trying to put everything into their mouths for information. Thus, increased vigilance must be given to children in this age group, as well as to the home environment, in order to remove the risk of poisoning ${ }^{(3,18)}$.

As for the origin of the victims, despite that the service is a referral service to Cuiaba and region, there were only a few victims that came from other municipalities, which can be explained by the fact that in this type of accident you need fast service, and victims were probably brought to health services in the same municipality of residence.

Regarding the classification of poisoning by ICD-10 according to age of the victim, other studies also show large proportion of pesticide poisoning in children under 4 years $(16,18,20)$. Thus, parents and guardians should be aware to store poisons out of reach of children, and to indiscriminately avoid the use of insecticides ${ }^{(21-22)}$.

On the other hand, the highest proportion of accidents from drugs in the ages of 5-9 years can be justified by the child's tendency to imitate adult behavior when viewing the same attitude displayed by their parents or other adults, carried out by the child when the medication is left within reach ${ }^{(18)}$.

The diversity in the type of intoxication among victims aged 10-14, draws attention in order to consider the compression capacity in this age group, instructing about the risks and prevention of intoxication and accidental poisoning ${ }^{(21)}$.

The fact that there was no occurrence of intoxication/ poisoning in patients over the age of 14 may be associated to the characteristic of the study, which included only accidental poisoning and not intentional as characterized by suicide attempts, and that are the most prevalent among adolescents and young people because they already have logical reasoning and free will, and a greater ability to understand the risks of certain products ${ }^{(4-13)}$. Another study sought to investigate accidental poisoning in cases recorded in the Poison Control Center at Maringá Regional University Hospital also found the maximum age of 14 years in unintentional poisoning ${ }^{(18)}$.

Despite not having statistical significance between the classification of intoxication and gender of the victims, the diversity of poisoning by drugs, chemicals and pesticides among both genders highlights the need for greater surveillance and intervention with security measures in the home environment. For example, store cleaning products in separate places which are inaccessible to children, do not leave medication in visible places and within easy reach, be aware of the risks of the various products used in the home environment, taking care not to use illegal products and/or changing the original packaging because, if swallowed, they can contact the Customer Service Center (SAC), and properly inform health professionals of the ingested product ${ }^{(15-21)}$.

As for the product involved in the poisoning, national and international studies also show that the aerosol insecticides, rodenticides and acaricides, detergents, bleaches, disinfectants, contraceptives, anticonvulsant analgesics, nasal decongestants, plants and chemicals or petroleum products are the main causes of unintentional poisoning among children of different ages ${ }^{(5,10-11,16,18)}$. Therefore, some preventive measures should be taken in the home environment, such as giving preference to packages of cleaning products and pharmaceuticals which have safety lids; keep medicines in hard to reach places and not visible to children; do not take medications in front of children and do not refer to them as "sweets," "jellybeans," or using nice/attractive adjectives; do not store petroleum products at home; avoid having poisonous plants at home; do not put cleaning products and pesticides in soft drinks bottles, especially if they have bright colors, etc. ${ }^{(21)}$.

Considering the dependence of children under one year, poisoning by rat poison, insecticide and aerosol insecticide relates to the use of these products by the adult without observing the child's presence there; analgesic, decongestant, and anticonvulsant poisoning, in turn, indicates errors from the dosage administered to the child ${ }^{(18)}$. Thus, greater attention should be paid by those responsible in order to avoid the use of poisons in the presence of children, as well as for proper dosage in administering pediatric drugs.

The poor quality of records in the records of emergency care was reflected in the lack of relevant information such as time of occurrence of the poisoning and the time elapsed between intoxication and care, thus suggesting the need for 
an intervention that promotes education and awareness of different health professionals for improving health records. However, it must be noted that most poisonings occur in the evening and at night ${ }^{(10)}$, which can be justified by children and adolescents being in the home environment during these periods, and also justification for the greatest number of poisonings on weekends. It is suggested that the attention of parents and guardians should be redoubled when children and adolescents are in the home environment, in addition to complying with the suggested care practices.

As for the month of occurrence, although April had the highest frequency of intoxication, there was no significant discrepancy between the other months of the year. A study in Palestine showed a higher frequency of poisoning in summer than in winter, with July and August being the months of highest incidence ${ }^{(12)}$. However, care in the home environment in addition to surveillance of children should both be increased throughout the year in order to reduce the risk for poisoning.

The primary assistance provided in large part by the health service and the fact that the victim's own mothers usually brought the victim to the emergency room may denote a lack of knowledge of parents and caregivers on how to immediately react when confronted with an accidental poisoning. A study in a children's hospital in São Paulo on the knowledge of parents for the first reaction to household accidents revealed that, for rescuing child victims of poisoning, parents had the lowest unanimity among the answers, suggesting the need for clarification on the subject ${ }^{(23)}$.

According to instructions of the National Health Surveillance Agency, the degree of intoxication varies according to the toxicity of substances, and so the rescuer should first identify the agent through bottles, instructions and product labels to inform health professionals, as they may identify antidotes. One should try to immediately move the victim to the emergency room, keeping them warm. At home, you can induce vomiting in case of food, drugs, alcohol, pesticide, shampoo, mothballs, mercury and ornamental plant poisoning. Never induce vomiting or give water or milk to unconscious victims or victims intoxicated from corrosive and petroleum-based substances (caustic soda, acids, bleaches, water with lime, ammonia, deodorant, kerosene) ${ }^{(24)}$.

A similar result was found in a study showing that $72.4 \%$ of calls to poison control centers occurred within the first two hours after poisoning ${ }^{(15)}$.

For clinical evolution of the victims of intoxication, similar results were found in a study of drug poisoning in children under 18, which showed $24.1 \%$ remained in hospital after emergency treatment ${ }^{(25)}$, which indicates the need for follow-up and monitoring of vital signs after poisoning, pointing to the seriousness of this type of accident in the home.

\section{CONCLUSION}

This study demonstrated a demand for emergency care due to poisoning by age group, in which the prevalence of victims were male and aged 1-4 years. Among children under one year, pesticide poisoning (rodenticides, acaridae and insecticide aerosol) was most prevalent, between 1 and 4 years it was cleaning products (detergent, bleach, stain remover), between 5 and 9 years it was from pharmacological products (contraceptive, anticonvulsant, hypertension, eye drops, nasal decongestant), between 10 and 14 years old from plants (desert rose, dumbcane), and other products (petroleum, super glue bonding, thinner, cresol), cleaning and pharmacological products as described above. There was a higher frequency of intoxication on weekends and in the months of April and June. Almost all of the first calls were attended to by the health service, and it was the mother of the victim who brought it to their attention. No cases of immediate physically damaging poisoning were reported. More than half of the victims were discharged after treatment.

Taking into account that pesticides/rodenticides caused the greatest number of poisonings are those which have already had their sale prohibited (such as pellets which look like attractive candies from being pink granules), it becomes essential to control in order to curb their commercialization.

It is recommended that health services work with the communities to conduct community training activities for first aid about poisoning and intoxication accidents, and promote safe household environments for children and adolescents, to act effectively in assistance aimed at reducing the consequences and deaths from intoxication and poisoning, and join / support research and studies to increase and produce relevant current knowledge for intervention in this reality.

As a limitation, the study also identified the poor quality of information in the records of emergency care, because in many cases there was no identification of the time of the accident nor the cause of intoxication (by product). In this sense, the training of professionals for awareness of the importance of health records is fundamental.

New studies are essential in order to know the different spheres of reality for intoxication and poisoning accidents in children and adolescents.

\section{RESUMO}

Objetivo: Analisar o perfil de intoxicação e envenenamento acidental em ambiente domiciliar na população infantojuvenil (0-24 anos) atendida em um serviço de referência em urgência e emergência, durante o ano de 2013. Método: Estudo descritivo, transversal. Os dados foram analisados pelo Epi-Info, por meio de análises simples e bivariadas. O Projeto foi aprovado pelo Comitê de Ética em Pesquisa (protocolo 405.578). Resultados: Houve 45 intoxicações, das quais prevaleceu o sexo masculino (60,0\%) e idades entre 1-4 anos $(71,1 \%)$. Entre os menores de um ano houve maior frequência de intoxicação por pesticidas $(66,6 \%)$, entre 1-4 anos por produtos de limpeza $(34,4 \%)$ e 5-9 anos por farmacológicos (66,6\%). O primeiro atendimento foi prestado apenas em instituições de saúde, havendo internação em 24,4\% dos casos. Conclusão: Evidencia-se a importância da prevenção através de legislação que garanta maior segurança em embalagens de diversos produtos, além da conscientização da comunidade para eliminar riscos no ambiente domiciliar. 
DESCRITORES

Criança; Envenenamento; Acidentes Domésticos; Toxicologia; Enfermagem Pediátrica.

\section{RESUMEN}

Objetivo: Analizar el perfil de intoxicación y envenenamiento accidental en ambiente domiciliario en la población infantojuvenil (0-24 años) atendida en un servicio de referencia en urgencia y emergencia, durante el año 2013. Método: Estudio descriptivo, transversal. Los datos fueron valorados por Epi-Info, mediante análisis sencillos y bivariados. Aprobó el proyecto el Comité de Etica en Investigación (protocolo 405.578). Resultados: Hubo 45 intoxicaciones, de las que prevaleció el sexo masculino (60,0\%) y edades entre 1-4 años $(71,1 \%)$. Entre los menores de un año hubo mayor frecuencia de intoxicación por pesticidas (66,6\%), entre 1-4 años por productos de limpieza $(34,4 \%)$ y 5-9 años por farmacológicos $(66,6 \%)$. La primera atención fue prestada solo en instituciones de salud, habiendo ingreso hospitalario en el 24,4\% de los casos. Conclusión: Se evidencia la importancia de la prevención mediante legislación que asegure una mayor seguridad en los embalajes de diversos productos, además de la concientización de la comunidad, a fin de eliminar riesgos en el ambiente domiciliario.

\section{DESCRIPTORES}

Niño; Envenenamiento; Accidentes Domésticos; Toxicología; Enfermería Pediátrica.

\section{REFERENCES}

1. Leite EMA, Amorim LCA. Noções básicas de toxicologia [Internet]. Belo Horizonte: Departamento de Análises Clínicas e Toxicológicas, Faculdade de Farmácia, UFMG; 2006 [citado 2014 out. 14]. Disponível em: http://www.farmacia.ufmg.br/lato/APTOXG2006.doc

2. Fook SML, Azevedo EFD, Costa MM, Feitosa ILF, Bragagnoli G, Mariz SR. Avaliação das intoxicações por domissanitários em uma cidade do Nordeste do Brasil. Cad Saúde Pública. 2013;29(5):1041-5.

3. Werneck GL, Hasselmann MH. Intoxicações exógenas em crianças menores de seis anos atendidas em hospitais da região Metropolitana do Rio de Janeiro. Rev Assoc Med Bras. 2009;55(3):302-7.

4. Lira SVG, Silva JG, Abreu RNDC, Moreira DP, Vieira LJES, Frota FA. Intoxicações por pesticidas em crianças, adolescentes e jovens no município de Fortaleza (CE). Ciênc Cuid Saúde. 2009;8(1):48-55.

5. Martins CB, de Andrade SM, de Paiva PA. Envenenamentos acidentais entre menores de 15 anos em município da Região Sul do Brasil. Cad Saúde Pública. 2006;22(2):407-14.

6. Brasil. Ministério da Saúde. DATASUS. Informações em Saúde. Indicadores de morbidade e mortalidade [Internet]. Brasília; 2014 [citado 2014 out. 14]. Disponível em: http://www.datasus.gov.br

7. Brasil. Ministério da Saúde; Fundação Oswaldo Cruz. Sistema Nacional de Informações Tóxico-Farmacológicas - SINITOX. Casos registrados de intoxicação humana e envenenamento: região Centro Oeste [Internet]. Rio de Janeiro: FIOCRUZ; 2011 [citado 2014 out. 14]. Disponível em: http://www.fiocruz.br/sinitox

8. Mowry JB, Spyker DA, Cantilena LR Jr, Bailey JE, Ford M. 2012 Annual Report of the American Association of Poison Control Centers' National Poison Data System (NPDS): 30th annual report. Clin Toxicol (Phila). 2013;51(10):949-1229.

9. Patil A, Peddawad R, Verma VCS, Gandhi H. Profile of acute poisoning cases treated in a tertiary care hospital: a Study in Navi Mumbai. Asia Pac J Med Toxicol. 2014;3(1):36-40.

10. Adnan LHM, Kamaldin J, Mohamad N, Salatore SA, Suhaimi R, Zainuddin ND, et al. The risk of accidental chemical poisoning cases among children ( $\leq 12$ Years Old) admitted to Hospital University Sains Malaysia: 5 Years Review. J Clinic Toxicol. 2013;3(5):177.

11. Balme K, Roberts JC, Glasstone M, Curling L, Mann MD. The changing trends of childhood poisoning at a tertiary children's hospital in South Africa. S African Med J. 2012;102(3 Pt 1):142-6.

12. Sawalha AF, Sweileh WM, Tufaha MT, AI-Jabi DY. Analysis of the pattern of acute poisoning in patients admitted to a governmental hospital in Palestine. Basic Clin Pharmacol Toxicol. 2010;107(5):914-8.

13. Ferreira MC, Figueiredo, MAA. Epidemiologia das intoxicações humanas por raticidas no brasil. Gestão Saúde. 2013;4(3):861-70.

14. Silva CCS, Souza KS, Marques MFL. Intoxicações exógenas: perfil dos casos que necessitaram de assistência intensiva em 2007. Rev Bras Ciênc Saúde. 201;15(1):65-8.

15. Presgrave RF, Camacho LA, Villas Boas MH. A profile of unintentional poisoning caused by household cleaning products, disinfectants and pesticides. Cad Saúde Pública 2008;24(12):2901-8.

16. Lourenco J, Furtado BMA, Bonfim C. Intoxicações exógenas em crianças atendidas em uma unidade de emergência pediátrica. Acta Paul Enferm. 2008;21(2):282-6.

17. Brasil. Ministério da Saúde. Portaria GM n. 737, de 16 de maio de 2001. Dispõe sobre a Política Nacional de Redução da Morbimortalidade por Acidentes e Violências. Brasília; Diário Oficial da União, Brasília, 18 maio 2001. Seção 1e

18. Tavares ÉO, Buriola AA, Santos JAT, Ballani TSL, Oliveira MLF. Fatores associados à intoxicação infantil. Esc Anna Nery Rev Enferm. 2013;17(1):31-7.

19. Margonato FB, Thomson Z, Paoliello MMB. Determinantes nas intoxicações medicamentosas agudas na zona urbana de um município do Sul do Brasil. Cad Saúde Pública. 2008;24(2):333-41.

20. Abahussain EA, Ball DE. Pharmaceutical and chemical pediatric poisoning in Kuwait: a retrospective survey. Pharm Pract (Granada). 2010;8(1):43-9.

21. Pereira SFA, Garcia CA. Prevenção de acidentes domésticos na infância. Rev Enferm UNISA. 2009;10(2):172-7. 
22. Souza BG, Gonçalves MX, Reed E. Inseticidas domésticos-composição química, riscos e precauções na sua manipulação. Estudos. 2014;41(1):86-94.

23. Durães MRP, Toriyama ATM, Maia LFS. O conhecimento dos pais sobre como proceder diante de acidentes domésticos. Recien Rev Cient Enferm. 2012;2(6):5-14.

24. Brasil. Ministério da Saúde; Fundação Oswaldo Cruz, Núcleo de Biossegurança. Manual de Primeiros Socorros [Internet]. Rio de Janeiro: FIOCRUZ; 2003 [citado 2014 out. 14]. Disponível em: http://www.fiocruz.br/biosseguranca/Bis/manuais/biosseguranca/manualdeprimeirossocorros.pdf

25. Lin YR, Liu TH, Liu TA, Chang YJ, Chou CC, Wu HP. Pharmaceutical poisoning exposure and outcome analysis in children admitted to the pediatric emergency department. Pediatr Neonatol. 2011;52(1):11-7.

Financial Support: Coordenação de Aperfeiçoamento de Pessoal de Nível Superior (CAPES). Master's scholarship grant. 